\title{
Effect of Mandibular Advancement Device Therapy on the Signs and Symptoms of Temporomandibular Disorders
}

\author{
Ritva Näpänkangas ${ }^{1,2}$, Antti Raunio ${ }^{2,3}$, Kirsi Sipilä ${ }^{1,4}$, Aune Raustia ${ }^{1,2}$ \\ ${ }^{1}$ Department of Prosthetic Dentistry and Stomatognathic Physiology, Institute of Dentistry, University of Oulu, Finland. \\ ${ }^{2}$ Department of Oral and Maxillofacial Surgery, Oulu University Hospital, Finland. \\ ${ }^{3}$ Department of Oral and Maxillofacial Surgery, Institute of Dentistry, University of Oulu, Finland. \\ ${ }^{4}$ Institute of Dentistry, University of Eastern Finland, Finland and Oral and Maxillofacial Department, Kuopio University \\ Hospital, Finland.
}

\author{
Corresponding Author: \\ Ritva Näpänkangas \\ Department of Prosthetic Dentistry and Stomatognathic Physiology \\ Institute of Dentistry, University of Oulu \\ P.O. BOX 5281, FI-90014 \\ Finland \\ Phone: +358407137077 \\ Fax: +358 85375560 \\ E-mail: ritva.napankangas@,oulu.fi
}

\begin{abstract}
Objectives: Mandibular advancement device therapy is effectively used in the treatment of obstructive sleep apnea, but also several side effects in the masticatory system have been reported. The aim of this study was to evaluate the subjective symptoms and clinical signs of temporomandibular disorders connected to mandibular advancement device therapy.

Material and Methods: The material consisted of 15 patients ( 9 men and 6 women, mean age 51.1 years, range 21 to 70 years) diagnosed with obstructive sleep apnea (OSA). Subjective symptoms and clinical temporomandibular disorders (TMD) signs were recorded at the beginning of the treatment (baseline) and at 1-month, 3-month, 6-month and 24-month follow-ups. The degree of TMD was assessed using the anamnestic (Ai) and the clinical dysfunction index (Di) of Helkimo. For assessing the effect of TMD the patients were divided in discontinuing and continuing groups.

Results: According to Ai and Di, the severity of TMD remained unchanged during the follow-up in most of the patients. Temporomandibular joint (TMJ) crepitation was found more frequently in discontinuing patients at all follow-ups. The difference was statistically significant $(\mathrm{P}<0.05)$ at the six-month follow-up. Masticatory muscle pain during palpation was a frequent clinical sign at the baseline and during the follow-up period but the difference between discontinuing and continuing patients was not significant.

Conclusions: It seems that signs and symptoms of temporomandibular disorders do not necessarily increase during long-term mandibular advancement device therapy. However, it seems that patients with clinically assessed temporomandibular joint crepitation may discontinue their mandibular advancement device therapy due to temporomandibular disorders.
\end{abstract}

Keywords: orofacial pain; oral health; quality of life; visual analogue pain scale.

Accepted for publication: 4 December 2012.

To cite this article:

Näpänkangas R, Raunio A, Sipilä K, Raustia A. Effect of Mandibular Advancement Device Therapy on the Signs and Symptoms of Temporomandibular Disorders.

J Oral Maxillofac Res 2012;3(4):e5

URL: http://www.ejomr.org/JOMR/archives/2012/4/e5/v3n4e5ht.pdf

doi: $10.5037 /$ jomr.2012.3405 


\section{INTRODUCTION}

Mandibular advancement device (MAD) therapy is nowadays widely used in the treatment of mild-tomoderate obstructive sleep apnea (OSA) and socially disturbing snoring [1-5]. A MAD is also recommended for patients with severe sleep apnea who are unable to tolerate or refuse to use continuous positive airway pressure (CPAP) (AASM recommendation) [6-7]. The MADs have many different designs and they all produce a widening of the upper airways by holding the mandible forward. It has been also noticed that a MAD increases muscular tonus, which may augment the effect of the device [8].

Although MADs have been found to be effective in the treatment of sleep apnea and snoring several complaints have been reported [4,9-13]. In the early phase of the treatment excessive salivation, mouth dryness, dental and jaw discomfort in the morning have been recorded [10,14-17]. Moreover, several long-term follow-up studies have reported occlusal changes, i.e. change in incisor inclination and decrease in overjet and overbite [14-15, 17-21]. However, even though side effects are common over long periods of MAD use, they usually are mild and well tolerated by most patients [17].

Both an increase and a reduction in signs and symptoms of temporomandibular disorders (TMD) have been reported during long-term usage of a MAD $[\underline{15}, \underline{22}]$. It has been hypothesized that by inducing forward and downward position of the mandible the use of MAD effects on subjective symptoms and clinical signs of TMD. The aim of this study was to evaluate the subjective symptoms and clinical signs of temporomandibular disorders connected to the use of mandibular advancement device in the treatment of obstructive sleep apnea in a two-year follow-up.

\section{MATERIAL AND METHODS}

Altogether 23 patients (Figure 1) were referred to the Oral and Maxillofacial Department, Oulu University Hospital by a pulmologist for consultation regarding OSA treatment within the time period October 2003 May 2004. OSA was diagnosed at the Department of Pulmonary Medicine, Oulu University Hospital. Of the referred patients, $15 / 23$ patients $(9$ men and 6 women, mean age 51.1 years, range 21 to 70 years) were able to wear the device in a one-month follow-up and they were included in further analysis.

Subjective TMD symptoms and the body mass index (BMI) of the patients were recorded before a clinical stomatognathic examination carried out at the beginning of the treatment (baseline) and at 1-month, 3-month, 6-month and 24-month follow-ups. The subjective symptoms recorded included tiredness/ stiffness in the temporomandibular joints (TMJs), difficulty in mouth opening, pain in the TMJs during opening or other mandibular movements, facial pain or TMJ pain, ear pain, clicking/crepitation of the TMJs, and locking/luxation of the TMJs. The clinical stomatognathic examination included measurement of the ranges of mandibular movements (restricted maximal opening $<40 \mathrm{~mm}$, restricted maximal lateral or protrusive movement $<7 \mathrm{~mm}$ ), evaluation of deviation $>2 \mathrm{~mm}$ in the opening/closing movement of the mandible, evaluation of locking/luxation of the TMJs, recording TMJ sounds (clicking and crepitation), TMJ pain palpated laterally and posteriorly, recording pain during mandibular movements, and pain in the masticatory muscles during palpation (temporal, masseter, medial pterygoid, lateral pterygoid and posterior digastric muscles) [23]. Occlusal parameters were not included in this examination. Clinical stomatognathic examinations were carried out at all registrations by the same person (KS) specialized in prosthetic dentistry and stomatognathic physiology.

The degree of TMD pathology was evaluated using the anamnestic index ( $\mathrm{Ai} ; \mathrm{Ai}=$ no symptoms, $\mathrm{Ai}$ $\mathrm{I}=$ mild symptoms, Ai II = severe symptoms) and the clinical dysfunction index (Di) of Helkimo (Di $0=$ no dysfunction, Di I = mild dysfunction, Di II = moderate dysfunction, Di III = severe dysfunction) [24].

The MAD therapies were performed by the same person (RN) specialized in prosthetic dentistry and stomatognathic physiology. Hard acrylic devices were individually designed by means of dental impressions (Xantalgin Select Alginate, Heraeus Kulzer, USA) and occlusal registrations (Modern Materials ${ }^{\circledR}$ Yellow Bite Wax, Heraeus, USA). The devices were fabricated in the same dental laboratory by the same technician. Occlusal registration was performed with a George Gauge instrument (Peter T. George, Honolulu, Hawaii). The range of mandibular advancement was set to $50 \%$ of maximum protrusive movement (mean 5.44 $\mathrm{mm}$, range 3 to $8 \mathrm{~mm}$ ). The mandibular opening was $5 \mathrm{~mm}$ between the incisal edges of the central incisors (according to the George Gauge instrument). Air holes were constructed in front and laterally on both sides of the device. The patients were informed to use the device regularly during the night. The follow-up scheme included 1-month, 3-month, 6-month and 24-month clinical follow-ups. Between the follow-ups patients were instructed to contact the hospital if problems appeared concerning the treatment.

After three months polysomnography with the MAD in the mouth was performed at home with an Embletta PDS 


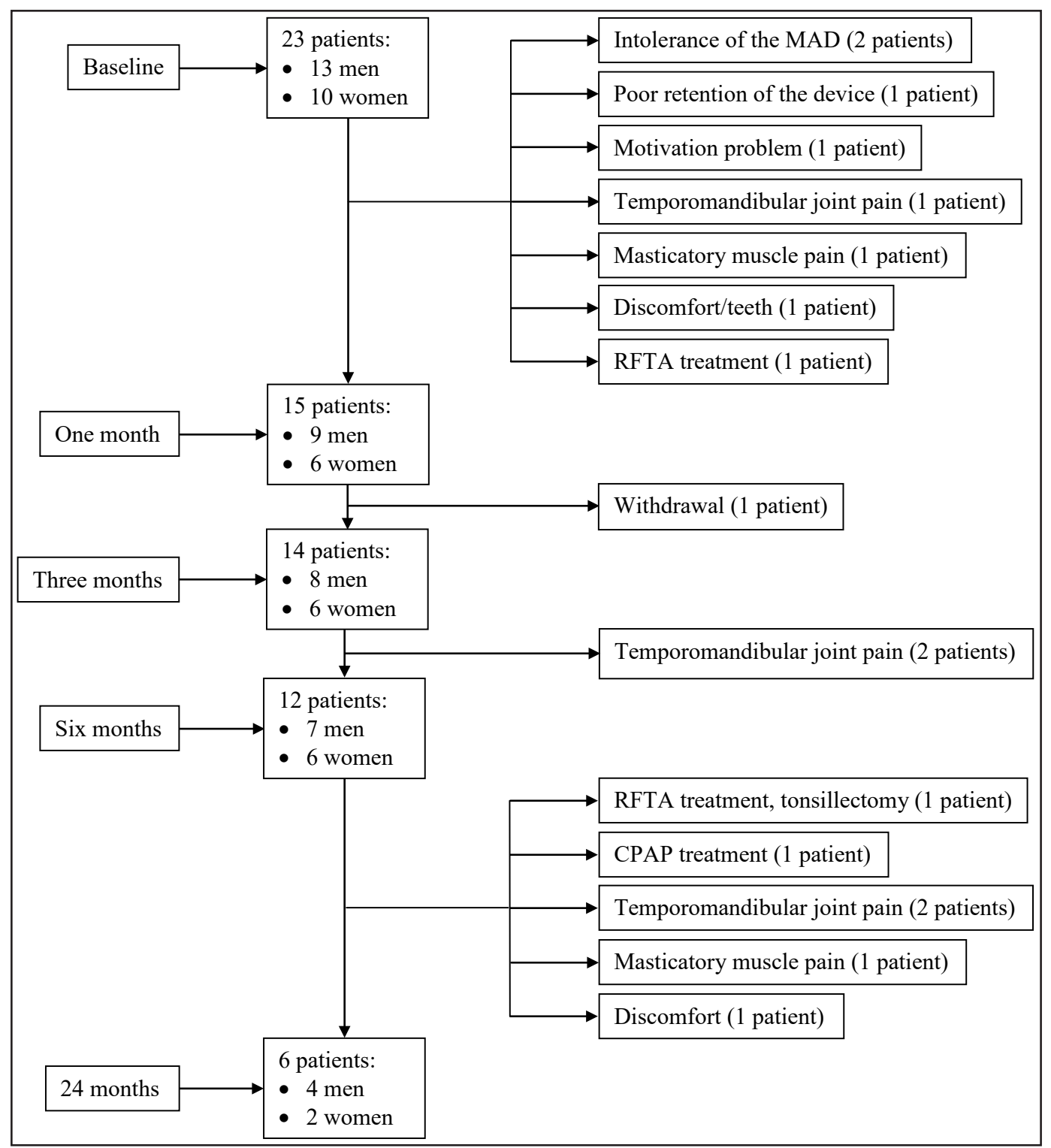

Figure 1. A flow chart of the patients with obstructive sleep apnea (OSA) treated with mandibular advancement device (MAD) therapy in follow-up examinations (baseline, one month, three month, six month and 24 month follow-ups) and the reasons for discontinuing the treatment between the follow-ups (paragraph on the right). RFTA = radio frequency ablation therapy; CPAP = continuous positive airway pressure therapy.

(Portable Diagnostic System) (ResMed Finland Oy), which is a pocket-sized digital recording device. The polysomnography analysis was done with Somnologica for Embletta software: in apnea-hypopnea index (AHI) a sleep apnea event was detected when a 10 seconds interval of the signal dropped below $10 \%$ of the reference amplitude. The reference amplitude was calculated as the mean value of the peak amplitudes found in a period of 100 seconds preceding the event. All events lasting longer than 120 seconds were excluded. A hypopnea event was detected when a 10 second(s) interval of the signal dropped below $70 \%$ of the reference amplitude. The reference amplitude was calculated as the mean value of the peak amplitudes found in a period of 100 seconds preceding the event. All events lasting longer than 120 seconds were excluded.
For a hypopnea to be scored, a desaturation event had to occur no later than 20 seconds after the start of the hypopnea.

\section{Statistical analysis}

Fisher's exact test was used to compare the clinical signs of TMD, and a Mann-Whitney test was performed to compare BMI, AHI with the device in the mouth and the age of the patient between the groups that continued the treatment vs. discontinued the treatment.

\section{RESULTS}

During the first month, eight patients $(8 / 23,35 \%)$ 
discontinued the treatment due to intolerance of the device, poor retention of the device, a motivation problem, TMJ pain, masticatory muscle pain or due to change into other treatment modality (Figure 1). One patient withdrew from the treatment before the 3-month follow-up. At the 6-month follow-up 12/15 patients $(80 \%)$ still wore the device. The reason for discontinuing the therapy was TMJ pain in two patients. At the 24-month follow-up examination 6/15 patients $(40 \%)$ were still wearing the MAD. The reasons for discontinuing the therapy were TMD symptoms (three patients), other treatment modalities (two patients) and discomfort (one patient).

The most frequent subjective symptoms at the baseline were ear pain and clicking and/or crepitation of the TMJ (Table 1). During the 24-month follow-up period, the most frequent subjective symptom of TMD was clicking and/or crepitation of the TMJ. According to the anamnestic dysfunction index (Table 2), most of the patients had no symptoms (Ai 0 ) or mild symptoms

Table 1. Subjective symptoms of the temporomandibular disorders (TMD) in patients treated with a mandibular advancement device (MAD) during a 24-month follow-up

\begin{tabular}{lccccc}
\hline \multicolumn{1}{c}{ TMD symptom } & $\begin{array}{c}\text { Baseline } \\
(\mathbf{n}=\mathbf{2 3})\end{array}$ & $\begin{array}{c}\mathbf{1} \text { month } \\
(\mathbf{n}=\mathbf{1 5})\end{array}$ & $\begin{array}{c}\mathbf{3} \text { months } \\
(\mathbf{n}=\mathbf{1 4})\end{array}$ & $\begin{array}{c}\mathbf{6} \text { months } \\
(\mathbf{n}=\mathbf{1 2})\end{array}$ & $\begin{array}{c}\mathbf{2 4} \text { months } \\
(\mathbf{n}=\mathbf{6})\end{array}$ \\
\hline Tiredness in the TMJs & 0 & 2 & 3 & 2 & 1 \\
Stiffness in the TMJs & 0 & 2 & 3 & 2 & 1 \\
Difficulty in jaw opening & 1 & 2 & 1 & 0 & 1 \\
TMJ Pain on jaw opening or other movements & 2 & 5 & 2 & 0 & 1 \\
Ear pain & 5 & 3 & 4 & 3 & 2 \\
Clicking and/or crepitation of the TMJ & 4 & 3 & 6 & 6 & 3 \\
Locking of the TMJs & 2 & 1 & 0 & 0 & 0 \\
\hline
\end{tabular}

$\mathrm{n}=$ number of patients; $\mathrm{TMJ}=$ temporomandibular joint.

Table 2. Distribution of the patients wearing a mandibular advancement device (MAD) and Helkimo anamnestic index (Ai) (Ai $0=$ no symptoms, Ai I = mild symptoms, Ai II = severe symptoms) and dysfunction index (Di) (Di $0=$ no clinical dysfunction (score 0), Di I = mild dysfunction (scores 1 - 4), Di II = moderate clinical dysfunction (scores 5 - 9), Di III = severe clinical dysfunction (scores 10 - 25) (Helkimo 1974) in a 24-month follow-up study

\begin{tabular}{|c|c|c|c|c|c|c|c|c|c|c|c|c|c|c|}
\hline 莺 & Sex & 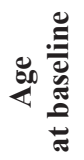 & BMI & 国 & 谣 & 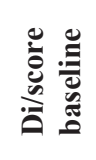 & そ & 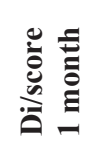 & 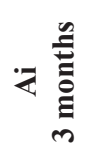 & 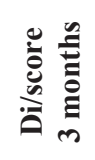 & 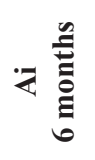 & 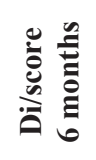 & 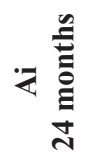 & 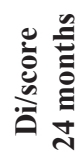 \\
\hline 1 & M & 47 & - & - & - & $\mathrm{I} / 1$ & - & - & - & - & - & - & - & - \\
\hline 2 & M & 48 & 22.4 & 1 & 0 & $\mathrm{II} / 7$ & I & $\mathrm{I} / 1$ & I & $\mathrm{II} / 5$ & I & $\mathrm{I} / 1$ & - & - \\
\hline 3 & $\mathrm{~F}$ & 46 & 27.7 & 2 & 0 & $\mathrm{II} / 5$ & II & $\mathrm{II} / 7$ & 0 & $\mathrm{II} / 5$ & 0 & $\mathrm{II} / 5$ & 0 & $\mathrm{II} / 5$ \\
\hline 4 & $\mathrm{M}$ & 43 & 26.6 & 1 & 0 & $\mathrm{I} / 1$ & 0 & $\mathrm{I} / 1$ & 0 & $\mathrm{I} / 1$ & 0 & $1 / 1$ & 0 & $\mathrm{I} / 1$ \\
\hline 5 & M & 51 & - & - & - & - & - & - & - & - & - & - & - & - \\
\hline 6 & M & 55 & - & - & - & - & - & - & - & - & - & - & - & - \\
\hline 7 & M & 59 & 37.9 & 46 & 0 & $\mathrm{II} / 6$ & 0 & $\mathrm{I} / 1$ & I & $\mathrm{I} / 1$ & I & $\mathrm{I} / 1$ & I & $\mathrm{I} / 1$ \\
\hline 8 & M & 39 & 24.9 & 7 & II & $\mathrm{II} / 8$ & II & $\mathrm{II} / 7$ & II & $\mathrm{II} / 8$ & I & $\mathrm{I} / 3$ & II & III/11 \\
\hline 9 & $\mathrm{~F}$ & 66 & 27.9 & 1 & 0 & $\mathrm{II} / 6$ & I & II/9 & 0 & II/7 & I & $\mathrm{I} / 3$ & - & - \\
\hline 10 & $\mathrm{~F}$ & 56 & 22.7 & 6 & II & III/12 & II & $\mathrm{III} / 12$ & II & $\mathrm{III} / 12$ & I & III/12 & - & - \\
\hline 11 & M & 50 & 27.7 & 26 & I & $0 / 0$ & I & $0 / 0$ & I & $0 / 0$ & & - & - & - \\
\hline 12 & $\mathrm{~F}$ & 60 & 24.7 & 9 & 0 & $\mathrm{I} / 2$ & 0 & $\mathrm{I} / 3$ & I & $\mathrm{I} / 2$ & I & $\mathrm{I} / 2$ & - & - \\
\hline 13 & $\mathrm{~F}$ & 54 & - & - & - & $\mathrm{I} / 2$ & - & - & - & - & - & - & - & - \\
\hline 14 & $\mathrm{~F}$ & 52 & - & - & - & - & - & - & - & - & - & - & - & - \\
\hline 15 & $\mathrm{~F}$ & 70 & 26.3 & 28 & I & $\mathrm{II} / 6$ & I & $\mathrm{II} / 7$ & I & $\mathrm{II} / 6$ & 0 & III/12 & I & $\mathrm{II} / 8$ \\
\hline 16 & M & 66 & 27.2 & 17 & 0 & $\mathrm{II} / 7$ & II & $\mathrm{II} / 7$ & 0 & $\mathrm{II} / 7$ & 0 & II/7 & 0 & $\mathrm{I} / 1$ \\
\hline 17 & M & 54 & - & - & - & $\mathrm{II} / 6$ & - & - & - & - & - & - & - & - \\
\hline 18 & M & 38 & 31.0 & 20 & I & $\mathrm{I} / 1$ & II & $\mathrm{I} / 2$ & I & $\mathrm{I} / 1$ & - & - & - & - \\
\hline 19 & M & 43 & - & - & - & $\mathrm{I} / 1$ & & $\mathrm{I} / 1$ & - & - & - & - & - & - \\
\hline 20 & $\mathrm{~F}$ & 55 & 23.1 & $<1$ & I & $\mathrm{I} / 1$ & I & $\mathrm{I} / 3$ & I & $\mathrm{I} / 3$ & I & $\mathrm{I} / 2$ & - & - \\
\hline 21 & $\mathrm{~F}$ & 45 & 25.7 & 3 & - & $\mathrm{II} / 6$ & - & - & - & - & - & - & - & - \\
\hline 22 & $\mathrm{~F}$ & 39 & 29.8 & $<1$ & - & $\mathrm{I} / 2$ & - & - & - & - & - & - & - & - \\
\hline 23 & M & 21 & 41.5 & - & 0 & $\mathrm{II} / 7$ & 0 & $\mathrm{II} / 6$ & 0 & II $/ 6$ & 0 & $\mathrm{II} / 5$ & - & - \\
\hline
\end{tabular}

$\mathrm{F}=$ female $\mathrm{M}=$ male. 
(Ai I) during the follow-up. In three patients the symptoms increased to severe symptoms (Ai II) from the baseline to the 1-month follow-up (numbers 3, 16 and 18), but the symptoms were relieved at the 6-month follow-up.

Masticatory muscle pain on palpation was a frequent clinical sign recorded at the baseline and during the follow-up period (Table 3), but the difference between the groups of discontinuing and continuing patients was not significant at any of the follow-ups (Table 4). Crepitation of the TMJ was found more frequently in discontinuing patients at all the follow-ups and the difference between the groups was significant at the 6-month follow-up $(\mathrm{P}<0.05)$.

Table 3. Clinical signs of the temporomandibular disorders (TMD) in patients treated with a mandibular advancement device (MAD) during a 24-month follow-up

\begin{tabular}{lccccc}
\hline \multicolumn{1}{c}{ TMD signs } & $\begin{array}{c}\text { Baseline } \\
(\mathbf{n}=\mathbf{2 3})\end{array}$ & $\begin{array}{c}\mathbf{1} \text { month } \\
(\mathbf{n}=\mathbf{1 5})\end{array}$ & $\begin{array}{c}\mathbf{3} \text { months } \\
(\mathbf{n}=\mathbf{1 4})\end{array}$ & $\begin{array}{c}\mathbf{6} \text { months } \\
(\mathbf{n}=\mathbf{1 2})\end{array}$ & $\begin{array}{c}\mathbf{2 4} \text { months } \\
(\mathbf{n}=\mathbf{6})\end{array}$ \\
\hline Restricted mandibular opening & 0 & 0 & 0 & 0 & 0 \\
\hline Clicking of the TMJ & 3 & 3 & 3 & 3 & 1 \\
\hline Crepitation of the TMJ & 6 & 5 & 5 & 5 & 2 \\
\hline Luxation of the TMJ & 0 & 0 & 0 & 0 & 0 \\
\hline Pain on palpation of the TMJ & & & & & \\
laterally & 1 & 1 & 0 & 0 & 0 \\
posteriorly & 1 & 2 & 1 & 0 & 0 \\
\hline Pain on palpation & & & & & \\
Temporal muscle- posterior part & 0 & 1 & 0 & 0 & 0 \\
Temporal muscle- anterior part & 0 & 1 & 1 & 0 & 0 \\
Temporal muscle- insertion & 9 & 8 & 7 & 5 & 2 \\
Masseter muscle & 4 & 6 & 5 & 3 & 1 \\
Medial pterygoid muscle & 5 & 3 & 3 & 4 & 2 \\
Lateral pterygoid muscle & 8 & 11 & 7 & 5 & 1 \\
Posterior digastric muscle & 9 & 11 & 8 & 7 & 2 \\
\hline
\end{tabular}

$\mathrm{n}=$ number of patients; $\mathrm{TMJ}=$ tmporomandibular joint.

Table 4. Clinical signs of temporomandibular disorders (TMD) in the patients who discontinued or continued the mandibular advancement device (MAD) therapy during a 24-month follow-up

\begin{tabular}{|c|c|c|c|c|c|c|c|c|c|c|c|c|}
\hline \multirow[b]{2}{*}{ TMD signs } & \multicolumn{3}{|c|}{ Baseline } & \multicolumn{3}{|c|}{$\begin{array}{c}1 \text { month } \\
(n=15)\end{array}$} & \multicolumn{3}{|c|}{$\begin{array}{c}3 \text { months } \\
(\mathrm{n}=14)\end{array}$} & \multicolumn{3}{|c|}{$\begin{array}{c}6 \text { months } \\
(\mathrm{n}=12)\end{array}$} \\
\hline & 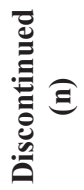 & 总 & $\mathbf{P}$ & 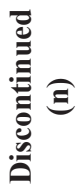 & 兽 & $\mathbf{P}$ & 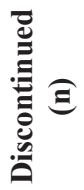 & ఏ & $\mathbf{P}$ & ڤ & 冚 & $\mathbf{P}$ \\
\hline Restricted mandibular opening & 0 & 0 & , & 0 & 0 & , & 0 & 0 & , & 0 & 0 & , \\
\hline Clicking of the TMJ & 2 & 1 & 0.569 & 1 & 2 & 0.569 & 1 & 2 & ${ }^{\mathrm{a}}$ & 0 & 3 & 0.061 \\
\hline Crepitation of the TMJ & 5 & 1 & 0.119 & 4 & 1 & 0.282 & 4 & 1 & 0.242 & 5 & 0 & 0.015 \\
\hline Luxation of the TMJ & 0 & 0 & , & 0 & 0 & , & 0 & 0 & , & 0 & 0 & , \\
\hline $\begin{array}{l}\text { Pain on palpation of the TMJ } \\
\text { laterally } \\
\text { posteriorly }\end{array}$ & $\begin{array}{l}0 \\
0 \\
\end{array}$ & $\begin{array}{l}1 \\
1 \\
\end{array}$ & & $\begin{array}{l}0 \\
2 \\
\end{array}$ & $\begin{array}{l}1 \\
0 \\
\end{array}$ & $\begin{array}{l}0.467 \\
0.467 \\
\end{array}$ & $\begin{array}{l}0 \\
1 \\
\end{array}$ & $\begin{array}{l}0 \\
0 \\
\end{array}$ & a & $\begin{array}{l}0 \\
0 \\
\end{array}$ & $\begin{array}{l}0 \\
0 \\
\end{array}$ & , \\
\hline Pain on palpation & & & & & & & & & & & & \\
\hline Temporal muscle - posterior part & 0 & 0 & , & 1 & 0 & a & 0 & 0 & , & 0 & 0 & , \\
\hline Temporal muscle - anterior part & 0 & 0 & , & 1 & 0 & a & 1 & 0 & a & 0 & 0 & , \\
\hline Temporal muscle - insertion & 4 & 5 & 0.608 & 5 & 3 & 0.619 & 5 & 2 & 0.242 & 2 & 3 & 0.567 \\
\hline Masseter muscle & 2 & 2 & a & 2 & 4 & 0.315 & 3 & 2 & a & 2 & 1 & a \\
\hline Medial pterygoid muscle & 2 & 3 & 0.608 & 2 & 1 & a & 1 & 2 & a & 2 & 2 & a \\
\hline Lateral pterygoid muscle & 5 & 3 & 0.619 & 7 & 4 & 0.282 & 4 & 3 & a & 2 & 3 & 0.567 \\
\hline Posterior digastric muscle & 5 & 4 & a & 6 & 5 & a & 4 & 4 & a & 4 & 3 & a \\
\hline
\end{tabular}

$\mathrm{n}=$ number of patients; $\mathrm{TMJ}=$ tmporomandibular joint.

${ }^{\mathrm{a} P}=1.000$. 
According to the clinical dysfunction index of Helkimo, the severity of TMD remained unchanged during the follow-up in most of the patients (Table 2). In one patient (number 8) the signs of TMD increased from moderate to severe during the two-year MAD therapy and in one patient (number 16) the signs decreased.

BMI, AHI with the device in the mouth and the age of the patient did not have any statistically significant differences between the groups that continued or discontinued the MAD therapy $(\mathrm{P}=0.898, \mathrm{P}=0.784$ and $\mathrm{P}=0.584$, respectively).

\section{DISCUSSION}

Based on this study, it seems that patients with existing TMJ crepitation discontinue their MAD therapy more often than patients without this finding. Although masticatory muscle pain on palpation was also a frequent clinical sign, the difference between the groups of discontinuing and continuing patients was not significant. The severity of TMD remained unchanged during the follow-up in most of the patients. It has been shown in a recent study that MAD therapy is associated in a short-time follow-up with more painrelated signs and symptoms of TMD and increased TMJ pain compared with CPAP therapy, but after 1 and 2 years a decrease of TMD was observed [25]. Our results can agree the authors' conclusion that due to the transient nature of TMD, possible development of TMJ pain or TMD should not be a contra-indication for oral appliance therapy in OSA patients [25]. Compared to CPAP, patients with mild to moderate sleep apnea (low $\mathrm{AHI}$ ) and few diurnal symptoms have been shown to fare better with intraoral appliances [2]

The MAD produces a mandibular protrusive position and the interincisal distance is $5 \mathrm{~mm}$ according to the occlusal registration with the George Gauge instrument. In regular every-night and long-term use this can be suspected to affect the TMJ as well as the masticatory muscles. In our study the most common subjective TMD symptom was clicking and/or crepitation of the TMJ and the most common clinical TMD sign was masticatory muscle pain. Subjective symptoms were increased in three patients at the 1-month follow-up compared with the baseline, but the symptoms were relieved during the later follow-up. In two patients the appearance of TMD led to withdrawal from the therapy in the early phase of the MAD treatment.

Walker-Engström et al. [26] have reported 62\% compliance after four years and Fransson et al. [15] reported even $85 \%$ compliance after two years. Here only $6 / 23$ patients $(26 \%)$ continued the MAD therapy until the 24-month follow-up. At the beginning of the treatment the patients were told about the different treatment modalities and it can be assumed that in the appearance of side effects they probably easily wanted to discontinue the long-term MAD therapy and change to other therapy. In addition, soft devices have been reported to be tolerated better than hard devices that were used in our study [19], although custom-made devices in general have been shown to be more effective (AHI, snoring) than prefabricated, thermoplastic devices [27]. The strength of the present study is its relatively long follow-up time, but the limitations of this study are the small study sample and the lack of a control group. Leaving a group of sleep apnea patients non-treated would not have been ethical, because the patients had suffered from OSA diagnosed at the Department of Pulmonary Medicine. In most cases OSA is deleterious impairing the quality of life of the affected person. On the other hand, the comparable group of patients treated with another treatment modality was not able to achieve during this time period.

MAD treatment is widely accepted and recommended in the treatment of mild sleep apnea and socially disturbing snoring. In Finland the treatment is performed in most cases by specialists in prosthetic dentistry and stomatognathic physiology or orthodontics. Treatment of sleep apnea and snoring may increase in the future due to more knowledge about OSA and MAD treatment. It is important that the efficacy of the therapy is controlled with polysomnography and that the patients have regular follow-ups and are motivated to go through with the treatment $[\underline{16}, \underline{25}, \underline{28}]$. In addition, the patients have to be informed about the side effects of MAD therapy. If a MAD is not tolerated or ineffective, sleep apnea should be treated with other methods, including bimaxillary advancement surgery in cases of severe occlusal disturbances $[\underline{29}, \underline{30}]$, since these patients could be at a particular health risk [2].

It seems that signs and symptoms of temporomandibular disorders do not necessarily increase during long-term mandibular advancement device therapy. However, it seems that patients with clinically assessed temporomandibular joint crepitation may discontinue their mandibular advancement device therapy due to temporomandibular disorders. Longer clinical followup studies with a larger sample are needed to evaluate the effects of mandibular advancement devices on the signs and symptoms of temporomandibular disorders.

\section{ACKNOWLEDGMENTS AND DISCLOSURE STATEMENTS}

This study was approved by Ethical Committee of the Northern Ostrobothnia Hospital District (4/2004, 26.1.2004). The authors declare that they have no conflict of interests. 


\section{REFERENCES}

1. Sleep-related breathing disorders in adults: recommendations for syndrome definition and measurement techniques in clinical research. The Report of an American Academy of Sleep Medicine Task Force. Sleep. 1999 Aug 1;22(5):667-89. Review. [Medline: 10450601]

2. Hoekema A, Stegenga B, Wijkstra PJ, van der Hoeven JH, Meinesz AF, de Bont LG. Obstructive sleep apnea therapy. J Dent Res. 2008 Sep;87(9):882-7. [Medline: 18719218] [doi: 10.1177/154405910808700917]

3. Yoshida K. Oral device therapy for the upper airway resistance syndrome patient. J Prosthet Dent. 2002 Apr;87(4):42730. [Medline: 12011859] [doi: 10.1067/mpr.2002.123228]

4. Hoffstein V. Review of oral appliances for treatment of sleep-disordered breathing. Sleep Breath. 2007 Mar;11(1):1-22. Review. [Medline: 17136406] [doi: 10.1007/s11325-006-0084-8] [FREE Full Text]

5. arklund M, Stenlund H, Franklin KA. Mandibular advancement devices in 630 men and women with obstructive sleep apnea and snoring: tolerability and predictors of treatment success. Chest. 2004 Apr;125(4):1270-8. [Medline: 15078734] [doi: 10.1378/chest.125.4.1270]

6. Chan AS, Lee RW, Cistulli PA. Dental appliance treatment for obstructive sleep apnea. Chest. 2007 Aug;132(2):693-9. Review. [Medline: 17699143] [doi: 10.1378/chest.06-2038]

7. Lim J, Lasserson TJ, Fleetham J, Wright J. Oral appliances for obstructive sleep apnoea. Cochrane Database Syst Rev. 2006 Jan 25;(1):CD004435. Review. [Medline: 16437488]

8. Johal A, Gill G, Ferman A, McLaughlin K. The effect of mandibular advancement appliances on awake upper airway and masticatory muscle activity in patients with obstructive sleep apnoea. Clin Physiol Funct Imaging. 2007 Jan;27(1):47-53. [Medline: 17204038] [doi: 10.1111/j.1475-097X.2007.00714.x]

9. Gotsopoulos H, Chen C, Qian J, Cistulli PA. Oral appliance therapy improves symptoms in obstructive sleep apnea: a randomized, controlled trial. Am J Respir Crit Care Med. 2002 Sep 1;166(5):743-8. [Medline: 12204875] [doi: 10.1164/rcem.200203-2080C] [FREE Full Text]

10. Tegelberg A, Wilhelmsson B, Walker-Engström ML, Ringqvist M, Andersson L, Krekmanov L, Ringqvist I. Effects and adverse events of a dental appliance for treatment of obstructive sleep apnoea. Swed Dent J. 1999;23(4):117-26. [Medline: 10591454$]$

11. Fransson AM, Tegelberg A, Leissner L, Wenneberg B, Isacsson G. Effects of a mandibular protruding device on the sleep of patients with obstructive sleep apnea and snoring problems: a 2-year follow-up. Sleep Breath. 2003 Sep;7(3):131-41 [Medline: 14569524] [doi: 10.1007/s11325-003-0131-7]

12. Marklund M, Franklin KA, Sahlin C, Lundgren R. The effect of a mandibular advancement device on apneas and sleep in patients with obstructive sleep apnea. Chest. 1998 Mar;113(3):707-13. [Medline: 9515847] [doi: 10.1378/chest.113.3.707]

13. Machado MA, Juliano L, Taga M, de Carvalho LB, do Prado LB, do Prado GF. Titratable mandibular repositioner appliances for obstructive sleep apnea syndrome: are they an option? Sleep Breath. 2007 Dec;11(4):225-31. [Medline: 17440760$]$ [doi: $10.1007 / \mathrm{s} 11325-007-0109-\mathrm{y}]$

14. Bondemark L, Lindman R. Craniomandibular status and function in patients with habitual snoring and obstructive sleep apnoea after nocturnal treatment with a mandibular advancement splint: a 2-year follow-up. Eur J Orthod. 2000; 22: 53-60. [Medline: 10721245] [doi: 10.1093/ejo/22.1.53] [FREE Full Text]

15. Fransson AM, Tegelberg A, Johansson A, Wenneberg B. Influence on the masticatory system in treatment of obstructive sleep apnea and snoring with a mandibular protruding device: a 2-year follow-up. Am J Orthod Dentofacial Orthop. 2004; 126: 687-693. [Medline: 15592216] [doi: 10.1016/j.ajodo.2003.10.040]

16. Pantin CC, Hillman DR, Tennant M. Dental side effects of an oral device to treat snoring and obstructive sleep apnea. Sleep. 1999 Mar 15;22(2):237-40. [Medline: 10201069]

17. A follow-up study of dental and skeletal changes associated with mandibular advancement splint use in obstructive sleep apnea. Hammond RJ, Gotsopoulos H, Shen G, Petocz P, Cistulli PA, Darendeliler MA. Am J Orthod Dentofacial Orthop. 2007 Dec;132(6):806-14. [Medline: 18068601] [doi: 10.1016/j.ajodo.2005.08.047]

18. Marklund M. Predictors of long-term orthodontic side effects from mandibular advancement devices in patients with snoring and obstructive sleep apnea. Am J Orthod Dentofacial Orthop. 2006; 129: 214-221. [Medline: 16473713] [doi: 10.1016/j.ajodo.2005.10.004]

19. Marklund M, Franklin KA, Persson M. Orthodontic side-effects of mandibular advancement devices during treatment of snoring and sleep apnoea. Eur J Orthod. 2001 Apr;23(2):135-44. [Medline: 11398551] [doi: 10.1093/ejo/23.2.135] [FREE Full Text]

20. Doff MH, Hoekema A, Pruim GJ, Huddleston Slater JJ, Stegenga B. Long-term oral-appliance therapy in obstructive sleep apnea: a cephalometric study of craniofacial changes. J Dent. 2010 Dec;38(12):1010-8. Epub 2010 Sep 8. [Medline: 20831889] [doi:10.1016/j.jdent.2010.08.018]

21. Doff MH, Finnema KJ, Hoekema A, Wijkstra PJ, de Bont LG, Stegenga B. Long-term oral appliance therapy in obstructive sleep apnea syndrome: a controlled study on dental side effects. Clin Oral Investig. 2012 May 6. [Epub ahead of print] [Medline: 222562077] 
22. Petit FX, Pépin JL, Bettega G, Sadek H, Raphaël B, Lévy P. Mandibular advancement devices: rate of contraindications in 100 consecutive obstructive sleep apnea patients. Am J Respir Crit Care Med. 2002 Aug 1;166(3):274-8. [Medline: 12153957] [doi: 10.1164/rccm.2008167] [FREE Full Text]

23. Carlsson GE, Magnusson T. Management of temporomandibular disorders in the general dental practice. Berlin: Quintessence Publishing Co, Inc; 199924.

24. Helkimo M. Studies on function and dysfunction of the masticatory system. I. An epidemiological investigation of symptoms of dysfunction in Lapps in the north of Finland. Proc Finn Dent Soc. 1974 Apr;70(2):37-49. [Medline: 4831505]

25. Doff MH, Veldhuis SK, Hoekema A, Slater JJ, Wijkstra PJ, de Bont LG, Stegenga B. Long-term oral appliance therapy in obstructive sleep apnea syndrome: a controlled study on temporomandibular side effects. Clin Oral Investig. 2012 Jun;16(3):689-97. Epub 2011 May 3. [Medline: 21538074] [doi: 10.1007/s00784-011-0555-6]

26. Walker-Engström ML, Tegelberg A, Wilhelmsson B, Ringqvist I. 4-year follow-up of treatment with dental appliance or uvulopalatopharyngoplasty in patients with obstructive sleep apnea: a randomized study. Chest. 2002 Mar;121(3):739-46. [Medline: 11888954] [doi: 10.1378/chest.121.3.739]

27. Vanderveken OM, Devolder A, Marklund M, Boudewyns AN, Braem MJ, Okkerse W, Verbraecken JA, Franklin KA, De Backer WA, Van de Heyning PH. Comparison of a custom-made and a thermoplastic oral appliance for the treatment of mild sleep apnea. Am J Respir Crit Care Med. 2008 Jul 15;178(2):197-202. Epub 2007 Aug 2. [Medline: 17673699] [doi: 10.1164/rccm.200701-1140C] [FREE Full Text]

28. Lindman R, Bondemark L. A review of oral devices in the treatment of habitual snoring and obstructive sleep apnoea. Swed Dent J. 2001;25(1):39-51. Review. [Medline: 11392605]

29. Raunio A, Rauhala E, Kiviharju M, Lehmijoki O, Sindor GK, Oikarinen K. Bimaxillary Advancement as the Initial Treatment of Obstructive Sleep Apnea: Five Years Follow-Up of the Pori Experience. J Oral Maxillofac Res. 2012;3(1):e5. [doi: $10.5037 /$ jomr.2012.3105]

30. Hoekema A, de Lange J, Stegenga B, de Bont LG. Oral appliances and maxillomandibular advancement surgery: an alternative treatment protocol for the obstructive sleep apnea-hypopnea syndrome. J Oral Maxillofac Surg. 2006 Jun;64(6):886-91. [Medline: 16713801] [doi: 10.1016/j.joms.2005.11.041]

\section{To cite this article:}

Näpänkangas R, Raunio A, Sipilä K, Raustia A. Effect of Mandibular Advancement Device Therapy on the Signs and Symptoms of Temporomandibular Disorders.

J Oral Maxillofac Res 2012;3(4):e5

URL: http://www.ejomr.org/JOMR/archives/2012/4/e5/v3n4e5ht.pdf

doi: $10.5037 /$ jomr.2012.3405

Copyright (C) Näpänkangas R, Raunio A, Sipilä K, Raustia A. Accepted for publication in the JOURNAL OF ORAL \& MAXILLOFACIAL RESEARCH (http://www.ejomr.org), 4 December 2012.

This is an open-access article, first published in the JOURNAL OF ORAL \& MAXILLOFACIAL RESEARCH, distributed under the terms of the Creative Commons Attribution-Noncommercial-No Derivative Works 3.0 Unported License, which permits unrestricted non-commercial use, distribution, and reproduction in any medium, provided the original work and is properly cited. The copyright, license information and link to the original publication on (http://www.ejomr.org) must be included. 